\title{
Growth and Instability of Major Millets in Andhra Pradesh, India
}

\author{
Ashwini, I. Byaligoudra ${ }^{1}$, B. Aparna, N. Vani ${ }^{1}$ and G. Mohan Naidu ${ }^{2}$ \\ ${ }^{1}$ Department of Agricultural Economics, ${ }^{2}$ Department of Statistics and Computer \\ Applications, S.V AgriculturalCollege, Tirupati-517 502, A.P., India
}

*Corresponding author

\section{A B S T R A C T}

\section{Keywords}

Compound growth rate, Instability index, Cuddy Della Valle index

Article Info

Accepted:

10 June 2019

Available Online:

10 July 2019
Indian agriculture history is witness of the new agriculture arrangement which took place in India has changed the overall traditional cropping pattern in India as well as in Andhra Pradesh such as green revolution and economic reforms. All these reforms have directly affected the productivity and production of only a few crops but the millets and pulses are going to highest instable in area and production in Andhra Pradesh. The growth rates and coefficient of variation of major millets were analyzed for period from 1990-2017 for the major five districts of Andhra Pradesh. In case of sorghum Guntur showed a high growth rates but high instability in production and yield. In case of bajra, yield showed increasing trend and area showed declining trend in majority of districts and state level also. Growth rates in ragi, korra and samai with respect to their area were negative in selected districts and state. The yield growth rate of total major millets found to be increasing in all selected districts and at state level with medium to high variation. The estimates of instability index in area, production and yield of millet crops showed a high variation in majority of the districts of Andhra Pradesh.

\section{Introduction}

Millet are the small -seeded grasses which are also called as nutri-cereals or dryland cereals which includes sorghum, bajra, ragi, small millet, proso millet, barnyard millet, kodo millet, foxtail millet, etc. Millets are particularly high in minerals like iron, magnesium, phosphorous and potassium. Finger millet (ragi) is the richest in calcium content, about 10 times that of rice or wheat. Millets are cultivated in low- fertile soils, tribal, mountainous and rainfed-areas which include Andhra Pradesh, Chattisgarh, Gujarat, Haryana, Karnataka, Tamilnadu and some other states.

The world's millet production was estimated at 28.45 million tons (FAOSTAT, 2017). India is the largest producer of millets with a 41.04 per cent global market share. The importance of millet as food staples has been declining from the last two decades, particularly in India, due to various reasons, including government policies, rising incomes and growing urbanization. Pearl millet is the 
most cultivated millet, grown predominantly in India and parts of Africa.

Andhra Pradesh is popularly known as granary of South India because of its abounding surpluses in the production of food crops. The total area under food grains is 42.06 lakh hectares out of which cereals and millets account nearly 64.4 per cent (201718). Sorghum, bajra, ragi, korra, varugu, samai are the various millets grown in the state among which sorghum, bajra and ragi constitutes 91 per cent of total area among these millets. Government is also taking initiatives to encourage farmers to go for millet cultivation.

In India, the year 2018 was declared as national year of millets and the year 2023 is going to be international year of millets as declared by FAO. Hence the present situation in cultivation of millets rightly deserves a renewed attention because of various factors affecting the area, production and yield of the millet crops.

The study has been undertaken (1) to estimate compound growth rates and (2) instability in area, production and productivity of major millets like sorghum, bajra, ragi, korra, samai and total major millets in Andhra Pradesh.

\section{Materials and Methods}

The study made use of time series data spanning from 1991-2017, covering the area, production, productivity, farm harvest prices and rainfall of selected millets. Sorghum is one of the important crops among millet and five districts are selected which all accounts for 50 percent share in the gross in Andhra Pradesh. Data sources were the various publications released by Directorate of Economics and Statistics, Andhra Pradesh. Nerlovian model was used for data analysis.

\section{Compound growth rates}

Compound growth rates will be estimated for the period from 1990-91 to 2017-18 with the following exponential model using least square techniques which are given below:

$$
Y=a b^{t}
$$

Where,

$\mathrm{Y}=$ Trend value of dependent variable (area/ total production/yield)

$\mathrm{a}=$ Constant

$b=$ Trend coefficient (slope of line)

$\mathrm{t}=$ Time variable (Years)

The function takes the form of a linear equation in logarithmic and become loglinear as under:

$\log Y=\log a+\log b$

Compound growth rate $(\mathrm{CGR})=($ Antilog $b$ 1) $* 100$

\section{Instability analysis}

To measure the instability in area, production and yield, an index of instability was used as a measure of variability. For comparing the variability present in them, coefficient of variation is used, which is expressed in percentage term. It is defined by the following formula.

$\mathrm{CV}(\%)=\frac{S D}{\mathrm{M}} \times 100$

Where,

C.V = Coefficient variation

$\mathrm{M}=$ Mean value of the variate

$\mathrm{SD}=$ Standard deviation of the variate 
The simple co-efficient of variation (CV) often contains the trend component and thus, over estimates the level of instability in time series data characterized by long-term trends. The Cuddy Della Valle Index de-trends the annual price and shows the exact direction of the instability (Cuddy and Della Valle, 1978). Hence, it is a better measure to capture instability in agricultural production and prices. A low value of this index indicates low instability in prices and vice-versa. The Cuddy-Della Valle index corrects the $\mathrm{CV}$ as:

Cuddy - Della Valle Instability Index $(\%)=$ C. $V \times\left(\sqrt{1-\overline{\mathrm{R}^{2}}}\right)$

Where, C.V is the Coefficient of Variation in per cent, and $\overline{\mathbf{R}^{2}}$ is the coefficient of determination from a time trend regression adjusted for its degrees of freedom.

The ranges of instability index are as follows; (Siba et al., 2017).

\begin{tabular}{|l|l|}
\hline Category & $\begin{array}{l}\text { Instability index } \\
\text { values rage }\end{array}$ \\
\hline Low & $0-15 \%$ \\
\hline Moderate & $15.01-29.99 \%$ \\
\hline high & $>=30 \%$ \\
\hline
\end{tabular}

\section{Results and Discussion}

\section{Growth rates of selected major millets}

\section{Sorghum}

In case of area of sorghum, all the districts and Andhra Pradesh has shown declining trend except the growth rates in Guntur which showed higher, positive and significant results in area (11.93 per cent), production (25.09 per cent) and yield (11.74 per cent) of the sorghum. The growth trend in production has shown positive growth in Andhra Pradesh by 1.28 per cent and declining trend in Prakasam district and Ananthapur by -0.04 and -6.72 per cent respectively, while the growth of productivity seemed to be increasing in the Kurnool, Prakasam and state level studies (Saraswati et al., 2012) due to wide spread use of high yielding varieties coupled with irrigation and fertilizer application might have led to increase in productivity of sorghum (Table 1).

\section{Bajra}

Table 2 revealed that the majority of the selected districts, Andhra Pradesh and India have shown a and negative growth in area and positive growth in productivity of bajra which might be due to replacement of the crop with other crops while increase in yield might be due to use of high yielding varieties and use of technology. In case of production state level study showed declining trend, the similar result was shown by Narwade (2013) on bajra production in Andhra Pradesh which was due to decline in area under the crop. All India level study showed positive growth.

\section{Ragi}

Estimation of growth rates of area, production and yield of ragi showed that there was declining trend in area and production of the crop in all the selected districts, Andhra Pradesh and all India level also as shown in Table 3. Among them Srikakulam district showed highest negative growth rate in area (9.77 per cent) as well as production ( -9.59 per cent) followed by Vizayanagaram district which might be due to replacement of area under crop with other crops such as paddy, sugarcane and also low market price for the crop.

\section{Korra}

The growth rate in area and production of korra showed declining trend at district level and state level analysis, however the yield 
growth rates worked out for the entire period showed a positive increase across districts and for Andhra Pradesh as a whole except Visakhapatnam. The better results in yield growth of korra (Table 4) showed that famers are using the new high yielding varieties, varieties resistant to pests and diseases and maintaining the soil fertility.

\section{Samai}

The growth trend in area of samai showed significant value for the state as a whole but production and yield of the crop did not show significant value. Among the districts, Vizayanagaram showed highest declining trend in area as well as production of samai by -13.67 and -10.85 per cent respectively which showed that the farmers are replacing the crop with other crops such as rice and sugercane. The growth trend in yield showed positive growth (Table 5), this might be due to better productivity of the soil and cultivation of crop in residual moisture of rice and sugarcane fields.

\section{Total major millets}

The analysis from Table 6 on growth trends in area, production and productivity of the total major millets showed better result in case of productivity where all the districts and state level studies showed increasing trend. Among the districts, West Godavari has shown positive growth in area (10.24 per cent), production (15.07 per cent) and also productivity (4.06 per cent), but the growth was more in area and production compared to productivity which may be due to decrease in fertility status of the soil or less diffusion of technologies.

\section{Instability of selected major millets}

\section{Sorghum}

The all India level results showed stability in all the three attributes i.e., area, production and yield of the crop and state level studies showed a moderate instability in both area and yield (Table 7), but high instability of 30.47 per cent in production (Krutika et al., 2017) which might be due to adoption of new technologies in cultivation of the crop, even though the area allocation is declining but there was no sudden drastic changes due to which moderate instability was observed. The district level studies showed that majority of the districts have high instability in area, production and productivity except Guntur with low instability index of 10.16 per cent in area, Kurnool with low instability in area by 13.92 per cent and moderate instability in production and yield by 25.99 and 20.11 per cent respectively.

\section{Bajra}

Estimation of instability in area, production and yield of bajrafrom Table 8 showed that there was low instability in area and moderate instability in production and productivity at all India level which means that the proportionality of area allocation was almost same every year but declining over the years and the instability in production and yield was might be due to changes in technology adoption. At state level, there was moderate instability in area by 24.72 per cent and high instability in production and yield of the crop by 31.58 and 35.69 per cent respectively (Rakesh, 2014). The district level study showed a high instability in all the three attributes except Kurnool in two attributes (area and yield) and Prakasam in case of yield. This might be due to replacement in cultivation of the crop with other crops like bengal gram and cotton in major bajra growing districts of Andhra Pradesh.

\section{Ragi}

The results from the Table 9 showed that the area, production and yield at all India level and State level were stable or low instability 
was observed. Among the districts Srikakulam showed a high instability in area and production (Ananthapur also by 31.56per cent) while moderate instability was observed in case of yield of the crop by 13.64 per cent which might be due to maintenance of fertility status of the soil and changes in cropping pattern whereas the other districts were found within the range of low and medium instability in area, production and yield of the crop.

Table.1 Compound growth rates in area, production and yield of sorghum

(In per cent)

\begin{tabular}{|c|c|c|c|c|}
\hline $\begin{array}{c}\text { Sl. } \\
\text { No }\end{array}$ & District/state/Country & Area & Production & Yield \\
\hline $\mathbf{1}$ & Kurnool & $-3.70 * * *$ & -0.30 & $3.52 * * *$ \\
\hline $\mathbf{2}$ & Guntur & $11.93 * * *$ & $25.09 * * *$ & $11.74 * * *$ \\
\hline $\mathbf{3}$ & Prakasam & $-3.81 * *$ & $-0.04 * *$ & 3.91 \\
\hline $\mathbf{4}$ & Kadapa & -1.36 & -0.00 & 1.25 \\
\hline $\mathbf{5}$ & Ananthapur & $-3.04 * * *$ & $-6.72 * * *$ & $-3.77 * * *$ \\
\hline $\mathbf{6}$ & Andhra Pradesh & $-2.95 * * *$ & $1.28 *$ & $4.36 * * *$ \\
\hline $\mathbf{7}$ & India & $-3.37 * * *$ & $-2.99 * * *$ & 0.20 \\
\hline *** Significant at 1 per cent level, ** Significant at 5 per cent level, * Significant at 10 per cent level
\end{tabular}

Table.2 Compound growth rates in area, production and yield of bajra

\begin{tabular}{|c|c|c|c|c|}
\hline Sl.no & District/state/Country & Area & Production & Yield \\
\hline $\mathbf{1}$ & Kurnool & $-4.02^{* * *}$ & -0.95 & $3.19 * * *$ \\
\hline $\mathbf{2}$ & Chittoor & $-2.46^{* * *}$ & 0.06 & $2.52 * * *$ \\
\hline $\mathbf{3}$ & Prakasam & $-1.82^{*}$ & 0.34 & $2.21 * * *$ \\
\hline $\mathbf{4}$ & Kadapa & 0.83 & 1.60 & 0.79 \\
\hline $\mathbf{5}$ & Ananthapur & $-2.65 * *$ & 0.64 & $3.30 * *$ \\
\hline $\mathbf{6}$ & Andhra Pradesh & $-4.61 * * *$ & $-2.05 * * *$ & $2.30 *$ \\
\hline $\mathbf{7}$ & India & $-1.18^{* * *}$ & $1.54 * * *$ & $3.12 * * *$ \\
\hline
\end{tabular}

*** Significant at 1 per cent level, ${ }^{* *}$ Significant at 5 per cent level, ${ }^{*}$ Significant at 10 per cent level

Table.3 Compound Growth rates in area, production and yield of ragi

\begin{tabular}{|c|c|c|c|c|}
\hline Sl.no & District/state/Country & Area & Production & Yield \\
\hline $\mathbf{1}$ & Visakhapatnam & $-3.04 * * *$ & $-2.82 * * *$ & 0.20 \\
\hline $\mathbf{2}$ & Chittoor & $-3.73 * * *$ & $-4.12 * * *$ & -0.32 \\
\hline $\mathbf{3}$ & Vizayanagaram & $-8.44 * * *$ & $-8.80 * * *$ & -0.40 \\
\hline $\mathbf{4}$ & Srikakulum & $-9.77 * * *$ & $-9.59 * * *$ & -0.23 \\
\hline $\mathbf{5}$ & Ananthapur & $-7.1 * * *$ & $-7.50 * * *$ & -1.09 \\
\hline $\mathbf{6}$ & Andhra Pradesh & $-5.12 * * *$ & $-5.65 * * *$ & $-0.56 * *$ \\
\hline $\mathbf{7}$ & India & $-2.44 * * *$ & $-1.42 * * *$ & $0.87 * * *$ \\
\hline
\end{tabular}

*** Significant at 1 per cent level, ** Significant at 5 per cent level, ${ }^{*}$ Significant at 10 per cent level 
Table.4 Compound growth rates of area, production and yield of korra

\begin{tabular}{|c|c|c|c|c|}
\hline Sl.no & District/state & Area & Production & Yield \\
\hline $\mathbf{1}$ & Kurnool & $-6.11 * * *$ & $-3.29 * *$ & $2.26 * * *$ \\
\hline $\mathbf{2}$ & Prakasam & $-12.05 * * *$ & $-10.07 * * *$ & $2.44 * * *$ \\
\hline $\mathbf{3}$ & Ananthapur & $-6.61 * *$ & $-5.12 * *$ & 1.12 \\
\hline $\mathbf{4}$ & Visakhapatnam & -7.71 & -8.17 & $-0.59 *$ \\
\hline $\mathbf{5}$ & Kadapa & -0.90 & -0.16 & $2.28 * *$ \\
\hline $\mathbf{6}$ & Andhra Pradesh & $-6.25 * * *$ & $-7.41 * * *$ & $3.9 * *$ \\
\hline
\end{tabular}

*** Significant at 1 per cent level, $* *$ Significant at 5 per cent level, $*$ Significant at 10 per cent level

Table.5 Compound growth rates of area, production and yield of samai

\begin{tabular}{|c|c|c|c|c|}
\hline SI. No & District/state & Area & Production & Yield \\
\hline $\mathbf{1}$ & Visakhapatnam & $-4.87 * * *$ & $-5.78^{* * *}$ & $-1.09 * *$ \\
\hline $\mathbf{2}$ & Chittoor & $-10.21 * * *$ & $-8.24 * * *$ & $2.06 * * *$ \\
\hline $\mathbf{3}$ & East Godavari & $-10.77 * * *$ & $-10.8 * * *$ & 0.57 \\
\hline $\mathbf{4}$ & Vizayanagaram & $-13.67 * * *$ & $-10.85 * * *$ & -1.36 \\
\hline $\mathbf{5}$ & Srikakulam & $-7.46 * * *$ & $-5.15 * * *$ & 0.02 \\
\hline $\mathbf{6}$ & Andhra Pradesh & $-5.46 * * *$ & -6.27 & -0.68 \\
\hline
\end{tabular}

*** Significant at 1 per cent level, ** Significant at 5 per cent level

Table.6 Compound growth rates of area, production and yield of total major millets

\begin{tabular}{|c|c|c|c|c|}
\hline Sl.no & District/state & Area & Production & Yield \\
\hline $\mathbf{1}$ & Visakhapatnam & $-5.27 * * *$ & $-4.12^{* * *}$ & $1.56^{* * *}$ \\
\hline $\mathbf{2}$ & Prakasam & -2.74 & 1.04 & $4.62^{* * *}$ \\
\hline $\mathbf{3}$ & Kurnool & $-3.28 * *$ & 0.68 & $5.61 * * *$ \\
\hline $\mathbf{4}$ & Ananthapur & -2.24 & -0.42 & $3.36 * *$ \\
\hline $\mathbf{5}$ & West Godavari & $10.24 * * *$ & $15.07 * * *$ & $4.06 * * *$ \\
\hline $\mathbf{6}$ & Andhra Pradesh & -0.24 & $6.49 * * *$ & $7.15^{* * *}$ \\
\hline
\end{tabular}

*** Significant at 1 per cent level, ** Significant at 5 per cent level

Table.7 Instability index in area, production and yield of sorghum

\begin{tabular}{|c|c|c|c|c|c|c|c|}
\hline \multirow{2}{*}{$\begin{array}{l}\text { SI. } \\
\text { no }\end{array}$} & \multirow{2}{*}{$\begin{array}{c}\text { District/State/ } \\
\text { Country }\end{array}$} & \multicolumn{2}{|c|}{ Area } & \multicolumn{2}{|c|}{ Production } & \multicolumn{2}{|c|}{ Yield } \\
\cline { 3 - 8 } & & $\mathbf{C V}$ & $\begin{array}{c}\text { Instability } \\
\text { index }\end{array}$ & $\mathbf{C V}$ & $\begin{array}{c}\text { Instability } \\
\text { index }\end{array}$ & CV & $\begin{array}{l}\text { Instabili } \\
\text { ty index }\end{array}$ \\
\hline $\mathbf{1}$ & Kurnool & 33.24 & 13.92 & 25.64 & 25.99 & 33.22 & 20.11 \\
\hline $\mathbf{2}$ & Guntur & 140.32 & 10.16 & 144.88 & 73.43 & 78.18 & 39.18 \\
\hline $\mathbf{3}$ & Prakasam & 88.01 & 101.63 & 73.5 & 74.90 & 54.19 & 44.81 \\
\hline $\mathbf{4}$ & Kadapa & 48.08 & 47.71 & 74.63 & 76.04 & 42.31 & 42.21 \\
\hline $\mathbf{5}$ & Ananthapur & 47.63 & 41.42 & 61.85 & 44.08 & 42.91 & 33.85 \\
\hline $\mathbf{6}$ & Andhra Pradesh & 34.56 & 23.66 & 31.78 & 30.47 & 38.45 & 18.38 \\
\hline $\mathbf{7}$ & India & 27.80 & 4.63 & 28.22 & 12.37 & 11.53 & 11.62 \\
\hline
\end{tabular}


Table.8 Instability index in area, production and yield of bajra

\begin{tabular}{|l|c|c|c|c|c|c|c|}
\hline \multirow{2}{*}{$\begin{array}{l}\text { Sl. } \\
\text { no }\end{array}$} & \multirow{2}{*}{$\begin{array}{c}\text { District/state/ } \\
\text { Country }\end{array}$} & \multicolumn{2}{|c|}{ Area } & \multicolumn{2}{|c|}{ Production } & \multicolumn{2}{|c|}{ Yield } \\
\cline { 4 - 8 } & & $\mathbf{C V}$ & $\begin{array}{c}\text { Instability } \\
\text { index }\end{array}$ & $\mathbf{C V}$ & $\begin{array}{c}\text { Instability } \\
\text { index }\end{array}$ & $\mathbf{C V}$ & $\begin{array}{c}\text { Instability } \\
\text { index }\end{array}$ \\
\hline $\mathbf{1}$ & Kurnool & 37.88 & 20.34 & 34.76 & 34.79 & 37.96 & 28.34 \\
\hline $\mathbf{2}$ & Chittoor & 39.02 & 32.06 & 43.2 & 44.02 & 36.54 & 31.98 \\
\hline $\mathbf{3}$ & Prakasam & 42.06 & 40.34 & 47.94 & 48.78 & 30.25 & 24.52 \\
\hline $\mathbf{4}$ & Kadapa & 43.28 & 43.43 & 47.07 & 36.07 & 32.17 & 32.14 \\
\hline $\mathbf{5}$ & Ananthapur & 56.95 & 53.49 & 74.93 & 76.19 & 66.77 & 61.56 \\
\hline $\mathbf{6}$ & Andhra Pradesh & 46.38 & 24.72 & 34.82 & 31.58 & 36.82 & 35.69 \\
\hline $\mathbf{7}$ & India & 11.80 & 7.28 & 21.67 & 18.36 & 28.96 & 15.59 \\
\hline
\end{tabular}

Table.9 Instability index in area, production and yield of ragi

\begin{tabular}{|l|c|c|c|c|c|c|c|}
\hline \multirow{2}{*}{$\begin{array}{l}\text { S. } \\
\text { no }\end{array}$} & $\begin{array}{c}\text { District/state/Cou } \\
\text { ntry }\end{array}$ & \multicolumn{2}{|c|}{ Area } & \multicolumn{2}{c|}{ Production } & \multicolumn{2}{c|}{ Yield } \\
\cline { 3 - 8 } & $\mathbf{C V}$ & $\begin{array}{c}\text { Instability } \\
\text { index }\end{array}$ & $\mathbf{C V}$ & $\begin{array}{c}\text { Instability } \\
\text { index }\end{array}$ & $\mathbf{C V}$ & $\begin{array}{c}\text { Instability } \\
\text { index }\end{array}$ \\
\hline $\mathbf{1}$ & Visakhapatnam & 24.65 & 7.32 & 30.80 & 20.92 & 17.26 & 17.52 \\
\hline $\mathbf{2}$ & Chittoor & 32.61 & 13.30 & 41.32 & 28.00 & 22.90 & 23.20 \\
\hline $\mathbf{3}$ & Vizayanagaram & 63.71 & 15.01 & 67.08 & 25.86 & 17.27 & 17.27 \\
\hline $\mathbf{4}$ & Srikakulum & 95.03 & 37.37 & 102.27 & 46.77 & 13.53 & 13.64 \\
\hline $\mathbf{5}$ & Ananthapur & 63.65 & 24.61 & 68.42 & 31.56 & 25.77 & 25.81 \\
\hline $\mathbf{6}$ & Andhra pradesh & 43.07 & 5.58 & 31.78 & 12.70 & 10.41 & 9.54 \\
\hline $\mathbf{7}$ & India & 21.10 & 6.10 & 17.89 & 14.51 & 13.17 & 11.52 \\
\hline
\end{tabular}

Table.10 Instability index in area, production and yield of korra

\begin{tabular}{|c|c|c|c|c|c|c|c|}
\hline \multirow{2}{*}{$\begin{array}{l}\text { SI. } \\
\text { no }\end{array}$} & \multirow{2}{*}{ Districts/State } & \multicolumn{2}{|c|}{ Area } & \multicolumn{2}{c|}{ Production } & \multicolumn{2}{c|}{ Yield } \\
\cline { 3 - 8 } & & $\mathbf{C V}$ & $\begin{array}{c}\text { Instabilit } \\
\text { y index }\end{array}$ & $\mathbf{C V}$ & $\begin{array}{c}\text { Instabilit } \\
\text { y index }\end{array}$ & $\mathbf{C V}$ & $\begin{array}{c}\text { Instabilit } \\
\text { y index }\end{array}$ \\
\hline $\mathbf{1}$ & Kurnool & 57.36 & 34.11 & 61.86 & 56.68 & 27.49 & 21.59 \\
\hline $\mathbf{2}$ & Prakasam & 117.94 & 88.53 & 157.92 & 128.73 & 43.90 & 39.89 \\
\hline $\mathbf{3}$ & Ananthapur & 97.63 & 87.68 & 109.84 & 106.45 & 43.61 & 40.72 \\
\hline $\mathbf{4}$ & Visakhapatnam & 102.90 & 80.18 & 116.62 & 92.76 & 36.21 & 36.58 \\
\hline $\mathbf{5}$ & Kadapa & 128.50 & 130.64 & 82.80 & 84.37 & 83.79 & 77.64 \\
\hline $\mathbf{6}$ & Andhra Pradesh & 64.96 & 42.00 & 80.47 & 57.36 & 24.18 & 22.51 \\
\hline
\end{tabular}


Table.11 Instability index in area, production and yield of samai

\begin{tabular}{|c|c|c|c|c|c|c|c|}
\hline \multirow{2}{*}{ Sl.no } & \multirow{2}{*}{ Districts/State } & \multicolumn{2}{|c|}{ Area } & \multicolumn{2}{c|}{ Production } & \multicolumn{2}{c|}{ Yield } \\
\cline { 3 - 8 } & & $\mathbf{C V}$ & $\begin{array}{c}\text { Instability } \\
\text { index }\end{array}$ & $\mathbf{C V}$ & $\begin{array}{c}\text { Instability } \\
\text { index }\end{array}$ & $\mathbf{C V}$ & $\begin{array}{c}\text { Instability } \\
\text { index }\end{array}$ \\
\hline $\mathbf{1}$ & Visakhapatnam & 35.59 & 14.48 & 46.61 & 23.27 & 26.34 & 24.69 \\
\hline $\mathbf{2}$ & Chittoor & 68.28 & 38.45 & 69.56 & 38.69 & 25.85 & 18.91 \\
\hline $\mathbf{3}$ & East Godavari & 72.32 & 33.12 & 97.41 & 38.60 & 37.73 & 37.95 \\
\hline $\mathbf{4}$ & Vizianagaram & 59.31 & 34.83 & 58.15 & 41.76 & 30.87 & 30.92 \\
\hline $\mathbf{5}$ & Srikakulam & 57.41 & 25.97 & 57.88 & 46.84 & 29.83 & 30.39 \\
\hline $\mathbf{6}$ & Andhra & 38.67 & 15.18 & 47.91 & 21.43 & 24.45 & 23.97 \\
& Pradesh & & & & & & \\
\hline
\end{tabular}

Table.12 Instability index in area, production and yield of total major millets

\begin{tabular}{|c|c|c|c|c|c|c|c|}
\hline \multirow{2}{*}{ Sl.no } & \multirow{2}{*}{ Districts/State } & \multicolumn{2}{|c|}{ Area } & \multicolumn{2}{c|}{ Production } & \multicolumn{2}{c|}{ Yield } \\
\cline { 3 - 8 } & & $\mathbf{C V}$ & $\begin{array}{c}\text { Instability } \\
\text { index }\end{array}$ & $\mathbf{C V}$ & $\begin{array}{c}\text { Instability } \\
\text { index }\end{array}$ & $\mathbf{C V}$ & $\begin{array}{c}\text { Instability } \\
\text { index }\end{array}$ \\
\hline $\mathbf{1}$ & Visakhapatnam & 41.78 & 24.26 & 37.37 & 33.26 & 23.40 & 20.51 \\
\hline $\mathbf{2}$ & Prakasam & 48.30 & 47.53 & 83.21 & 84.59 & 45.90 & 28.63 \\
\hline $\mathbf{3}$ & Kurnool & 32.82 & 30.83 & 56.56 & 57.55 & 50.10 & 27.66 \\
\hline $\mathbf{4}$ & Ananthapur & 40.87 & 40.98 & 47.84 & 34.55 & 38.77 & 35.59 \\
\hline $\mathbf{5}$ & West Godavari & 66.72 & 19.85 & 78.91 & 26.86 & 33.80 & 22.15 \\
\hline $\mathbf{6}$ & Andhra & 25.26 & 25.72 & 66.43 & 57.40 & 70.28 & 39.53 \\
\hline & Pradesh & & & & & & \\
\hline
\end{tabular}

\section{Korra}

Estimation of instability in korra from Table 10 showed that all the selected districts have shown a high variation in area, production and yield except Kurnool in case of yield of the crop with instability index of 21.59 per cent. Similar result was observed at state level study also except in case of productivity of the crop where medium instability was observed which is due to fertility status of the soil or cropping pattern.

\section{Samai}

The analysis from Table 11 depicted that Visakhapatnam showed a low variation in area by 14.48 per cent which means that the proportionate of area allocated under the crop was almost same in all the years of study period while majority districts, state level and all India level study showed a medium to high variation in all the attributes.

\section{Total major millets}

The Prakasam, Kurnool and Ananthapur have shown a high variation in area, production and yield of total major millets except the yield of the crop in Prakasam and Kurnool districts which showed a medium instability index (Table 12). West Godavari and Visakhapatnam district showed medium instability in case of all the area, production and productivity of the crop except the production attribute in case of Visakhapatnam which means that the low adoption technologies might have led to production 
instability of crop in the district. At state level, area showed medium instability in area by 25.72 per cent which means that the proportionate of area allocated by farmers was almost same during the study period, but production and productivity showed a high variation indicating that there might be less diffusion of technologies.

In conclusions, the growth rate of sorghum area, production and yield was increasing in Guntur district with high instability in area and production, whereas at state level production and yield growth rates were found to positive. In case of bajra, yield showed increasing trend and area showed declining trend in majority of districts and state level also. Growth rates in ragi, korra and samai with respect to their area were negative in selected districts and state. The yield growth rate of total major millets was found to be increasing in all selected districts and at state level with medium to high variation and among the districts, West Godavari district showed positive growth in all the attributes i.e., area, production and yield of total major millets. The estimates of instability index in area, production and yield of millet crops showed a high variation in majority of the districts. All India level study showed that low to moderate instability in sorghum, bajra and ragi.

\section{References}

Cuddy, J. D.A and Valle, P. A. D. 1978. Measuring the instability of time series data. Oxford Bulletin of Economics and
Statistics. 40:53-78.

Jitendra, S., Hari, S., Devendra, K. V and Pradeep, P. 2018. Inter year yield instability of major crops in Rajasthan agriculture. International Journal of Current Microbiology and Applied Sciences. Special Issue-7: 549-560.

Kumar, A. S and Phanindra, G. 2018.Agricultural growth and production variability of principal crops in India: an empirical investigation. Advances in Plants and Agriculture Research. 8(1): 45-51.

Pavithra, N. L., Ashalatha, K.V., Megha, J., Manjunath, G. R and Siddu, H. 2018. Growth in area, production and productivity of food grains in Karnataka State, India. International Journal of Current Microbiology and Applied Sciences. 7(8): 2532-2535.

Sagolsem, S., Mitra, A., and Leivang, S. 2017. Growth and instability analysis of major crops in North East India. Journal of Crop and Weed, 13(1): 7276.

Archana, M., Meena, R. L., Meena, N. K and Chiphang, S. 2018. Change in instability of area and production of major fruits and vegetables crops stored in cold storages. International Journal of Current Microbiology and Applied Sciences.7(2): 2262-2267.

Veerabhadrappa, B., Umesh, K. B and Ravi, S.C. 2016. Growth dynamics and forecasting of finger millet (Ragi) production in Karnataka. Economic Affairs. 61(2): 195-201.

\section{How to cite this article:}

Ashwini, I. Byaligoudra, B. Aparna, N. Vani and Mohan Naidu, G. 2019. Growth and Instability of Major Millets in Andhra Pradesh. Int.J.Curr.Microbiol.App.Sci. 8(07): 985-993. doi: https://doi.org/10.20546/ijcmas.2019.807.118 